\title{
H. L. A. HART: SUPERVISOR, MENTOR, FRIEND, INSPIRATION
}

\author{
W. J. WALUCHOW
}

Some of the ideas developed and defended in this book originated in my doctoral thesis, 'Adjudication and Discretion', submitted at Oxford University. I am delighted once again to acknowledge my overwhelming debt to Herbert Hart who supervised the thesis and provided me with the kind of guidance and encouragement of which doctoral students dreams are made. Professor Hart has continued to offer his insightful comments on my written work, and for his ongoing assistance and generosity I am extremely grateful.

So began the acknowledgments page of my book, Inclusive Legal Positivism. ${ }^{1}$ To this day, I continue to feel the force of Hart's influence, both in my philosophical work and, perhaps more importantly, in my relationships with friends, colleagues, and above all else, my students. We all know, quite well, the many fine scholarly qualities displayed in Hart's wide-ranging philosophical work: his sheer philosophical insight and clarity of thought; an ease of expresvi.

1 W. J. Waluchow, Inclusive Legal Positivism (Oxford: Clarendon Press, 1994), 
sion that often obscured the depth of his understanding; his appreciation of the immense complexity of the many important issues he addressed; the fairness and open-mindedness with which he dealt with opposing views; and his willingness to call a spade a spade when he found it necessary to do so. With the publication of Nicola Lacey's fascinating biography, we now know much more about Hart's complicated personal life. ${ }^{2}$ One aspect touched upon by Lacey is the scholarly relationships Hart shared with his students, many of whom went on to pursue successful academic careers of their own: Brian Barry, John Finnis, Neil MacCormick and Joseph Raz, to name just a few. In her final chapter, Lacey discusses Hart's complicated relationship with one of his most distinguished students, Ronald Dworkin, who went on to succeed Hart in the Oxford Chair of Jurisprudence, a post Dworkin held while I was a student in Oxford. As is well known, a good deal of Dworkin's early work consisted of a full-scale critique of Hart's legal positivism, a theory about the nature of law that Dworkin hoped to dislodge as "the ruling theory of law". ${ }^{3}$ In my doctoral dissertation, I attempted to defend Hartian positivism against Dworkin's powerful critique, and had the good fortune of being able to consult both scholars. Despite being officially retired, Hart agreed to supervise my doctoral dissertation, while Dworkin, while not officially attached to me in any way, graciously agreed to read some of my work.

I recall visiting Dworkin, on one memorable occasion in his rooms in New College, to discuss a very long paper I had written that dealt with his critique of Hart. This paper, which I had earlier submitted to Hart and which will figure prominently in the first of the two stories recounted below, contained the main lines of argument I would later develop both in my dissertation and, years later, in Inclusive Legal Positivism. One of Dworkin's first questions to me was:

\footnotetext{
2 Nicola Lacey, A Life of H. L. A. Hart: The Nightmare and the Noble Dream (Oxford, Oxford University Press, 2004).

3 Ronald Dworkin, Taking Rights Seriously (Cambridge, Harvard University Press, 1978), vi.
} 
"What does Herbert think of this?" to which I replied: "He seems to agree with the line of argument [inclusive legal positivism] it pursues". Dworkin shook his head in what I could only interpret as utter dismay. Despite this, he and I went on to have a very productive (at least for me) meeting. A few days after this encounter, I arranged to meet with Hart to get his take on another paper I had written. One of Herbert's first questions to me was: "What does Ronnie think of the paper you had him read?" to which I replied: "Not much". He smiled and we too went on to have a very productive meeting.

In her book, Professor Lacey recounts a bit of this story and takes it to signify the unfortunate rift that appeared to have developed between Hart and his distinguished student. Whether that is so is not for me to judge, and is certainly not a topic upon which I care to comment here. What I wish to do instead is share two further stories that reveal the kind of relationship Hart and I enjoyed and which, I can only imagine, he must have shared with most, if not all, of his other students. These stories will, I hope, serve not only to acknowledge further the enormous debt of gratitude I owe my supervisor. I hope they will also help solidify the conviction among many that in Herbert Hart what one encountered was a truly remarkable human being.

\section{The Nightmare and the Magnificent Dream}

When I first began at Oxford, I was assigned a supervisor who, much to my dismay, did not provide me with the type of supervision for which I had hoped. R. M. Hare, though highly accomplished in the field of moral philosophy, had little background or interest in the philosophy of law, the subject upon which I had decided to write. Despite this unfortunate situation I persisted, attempting as best I could to produce work that might someday form parts of a doctoral dissertation in the subject. But I was clearly floundering and knew myself that what I was coming up with just didn't 
pass muster. But I didn't know quite what to do about it. Well into my second year, I had the good fortune of encountering John Mackie at a legal theory conference in Lancaster, England. Upon hearing of my predicament Mackie kindly agreed to read my work upon his return to Oxford. I sent him everything I had written to that point, was duly summoned to his rooms, and was issued the verdict I had feared but expected: for the most part, the work just wasn't very good. There was one exception, however: a short piece on what was becoming known as "the Hart-Dworkin debate". The specific question upon which I had focused was whether Hart's positivism is, as Dworkin maintained, restricted to content-neutral, "pedigree" tests of legal validity. My answer was a resounding 'no' and I went on to argue that Hart's famous rule of recognition can easily accommodate conformity with a set of moral values and/or principles as a necessary condition of legal validity, something Hart himself had acknowledged in a variety of places, and which he later confirmed in his Postscript to The Concept of Law. ${ }^{4}$

Buoyed by Mackie's favourable judgment of the piece, I endeavoured to develop it. [It eventually morphed into the longish paper mentioned in the preceding section, the one on which Hart and Dworkin wanted to know the other's views.] I delivered it to Hare who suggested that perhaps we should solicit Hart's views on the paper. I was of course delighted with the idea, and so Hare, right on the spot, tele-

4 In an early paper, Hart made this suggestion: "Bentham indeed recognized, as Austin did not, that even the supreme legislative power might be subjected to legal restraints by a constitution and would not have denied that moral principles, like those of the fifth amendment, might form the content of such legal constitutional restraints." "Positivism and the Separation of Law and Morals" Harvard Law Review, Vol. 71, No. 4 (Feb., 1958), 599. See also The Concept of Law, 2nd ed. (Oxford: Clarendon Press, 1994), p. 204 where Hart suggests that "In some systems [of law], as in the United States, the ultimate criteria of validity explicitly incorporate principles of justice or substantive moral values." In the Postscript to his famous book (p. 250), Hart comments on Dworkin's attribution to him of exclusive or "plain-fact positivism" by noting that it "ignores my explicit acknowledgement that the rule of recognition may incorporate as criteria of legal validity conformity with moral principles or substantive values...". 
phoned Hart who agreed to read my paper. Soon thereafter, I deposited a copy in Hart's mailbox at University College. Before hearing back from Hart, whom I had not yet met, I was summoned to a meeting with Hare to discuss my paper and made my way to his study in Corpus Christi College. Upon entering Hare's room and preparing to take my usual place in the chair opposite his, I was, to put it quite simply, broadsided. Before I was able to take my seat Hare informed me that there was no need for me to sit down. He had not, he explained, "managed to read past page two. I have to confess", he added, "that I found your paper a frightful bore," at which point he handed it back to me and, without further ado, immediately went back to work. It is difficult to explain how distressed this left me. It seemed as if my scholarly career had just been issued a death sentence. It is one thing to be wrong; it is quite another to have laboured away for weeks only to come up with something one's supervisor had no interest in reading. There seemed nothing left for me to do except leave Corpus, take the bus home, and begin contemplating whether I should try to cobble together enough money for a flight back to Canada. What I had written was the best that I could come up with. If that wasn't worth reading, then it was obvious that the time had come to pursue another career.

Upon arriving at Wolfson College, where I had a college flat, I decided to check my mailbox. In it was a letter that changed my life and set me on my way to the career that I now enjoy. It was from Herbert Hart who had finished reading the paper I had submitted to him and which had just been the subject of Hare's less than positive reaction. Hart began with the following words - which are indelibly imprinted on my memory and which I will never forget: "My Dear Waluchow. I am reading with care and fascination your excellent chapter on Dworkin". Whereas words cannot capture how distressed I felt less than an hour ago in Hare's rooms, words cannot begin to express the feelings of utter elation I experienced upon reading this reaction to my 
work. Not only did H. L. A. Hart read my paper; and not only did he find it interesting and its arguments plausible. He found it "fascinating". Hart went on, in his letter, to issue an invitation to dinner at University College, and thus began a scholarly relationship that saw him eventually replace Hare as my doctoral supervisor and which I immensely enjoyed and from which I greatly profited until his death in 1992.

\section{The Supervisor of Which Graduate Dreams are Made}

My second story takes place in the final few months of my three-year stay in Oxford. Hart had, by this point, replaced Hare as my doctoral supervisor and I was diligently working away, trying to finish my dissertation by the end of the current academic year. Rough drafts of the final three chapters were complete, but much work had yet to be done. And then tragedy hit. My youngest brother died unexpectedly and I needed to be with family in Canada. My stay in Canada turned out to be longer than anticipated and upon my eventual return to Oxford, several weeks later, I faced what appeared to be an impossible task - completing the dissertation in an even shorter period of time. Many suggested that I abandon that objective and take an additional year to submit. For a variety of reasons this was an option that really didn't appeal to me. So I decided to give it my best shot. I would attempt to finish by the end of the current year, daunting and near-impossible as that task appeared to be. I completed my next chapter and, as per the usual practice, I submitted it to Hart, expecting to be summoned within the next two to three weeks for discussion and criticism. The next morning I heard a gentle knock on the front door of my apartment which, I hasten to add, was in Kennington, a small village some five miles outside of Oxford. When I opened the door, I was astonished to find Herbert Hart, standing beside his bicycle, with my chapter in hand. As best as I can remember, this is more or less 
what he had to say: "I was out for a ride and thought I'd drop by to see if you wanted to discuss your chapter. I know you're working under a tight schedule". Despite the fact that neither I nor my apartment were in any shape to receive company, I invited Hart in. We met in my study for several hours discussing the chapter and the ones that were to follow. I managed to finish on time.

\section{Lessons Learned}

There is much we can all learn from the philosophy and philosophical approach of H. L. A. Hart. His many contributions to legal philosophy and its associated fields are and continue to be monumental. He stands among the giants of $20^{\text {th }}$ century philosophy of law and helped set in place a set of questions and modes of addressing them that persist to this day. About all this much has already been said and I will have nothing further to add here. But what I do want to add are some final thoughts on Hart the man, the supervisor, the friend. In reflecting on the two stories recounted above, I am struck by the enormous influence he had on my life and, I am sure, all those who had the great fortune to have known him. Herbert Hart was not only a talented, accomplished scholar. He was a kind, generous man who always made me feel like I counted both as a scholar and a person. When in his presence, I never once felt anything but complete support and understanding. Hart always conveyed his belief that my views on whatever issues we were discussing were worth considering, even though he was the master and I the student. I also learned, from Hart -and in a different way, Hare- how a few words can mean so very much, one way or the other, to a person struggling to make his mark in the world. Had I not had the great fortune of receiving Hart's letter after my meeting with Hare, I might never had gone on in philosophy and enjoyed whatever meager success I have had as an academic. Had I not been so lucky as to have a supervisor who was willing to drop ev- 
erything to help me meet an urgent deadline, I might never have finished my dissertation. These are the thoughts I entertain when I remember my supervisor and the pivotal role he played in helping to make me the scholar and person I am today. These are the thoughts I endeavour to keep firmly in mind when, in dealing with my own graduate students, I struggle to meet the very high standard he set for me. Thank you Herbert. 